\title{
RECESSION OF GRASSHOPPER GLACIER, MONTANA, SINCE 1898
}

\author{
by
}

\author{
Jane G. Ferrigno
}

(US Geological Survey, Reston, Virginia 22092, U.S.A.)

\begin{abstract}
Grasshopper Glacier is a cirque glacier in the central Rocky Mountains of the United States. It is a remnant of the "Little Ice Age", rather than the more widespread and older Pinedale Glaciation. The glacier has not been monitored on a regular basis and very few maps have been published of the area, but it has been studied, photographed, occasionally mapped, and described by scientific and non-scientific groups, at different times since 1898. These photographic, cartographic, and written records make it possible to trace the fluctuations of this glacier since 1898. Grasshopper Glacier has had periods of positive mass balance, but the overall trend has been negative, with accelerated melting in recent years. It is estimated that Grasshopper Glacier has lost about $50 \%$ of its area and as much as $90 \%$ of its volume, since 1898. Other Rocky Mountain glaciers are experiencing similar wastage and, if current conditions continue, these glaciers will disappear by the middle of the next century.
\end{abstract}

\section{INTRODUCTION}

Grasshopper Glacier is a small cirque glacier, located at approximately $45^{\circ} 08 \mathrm{~N}$. latitude and $109^{\circ} 53 \mathrm{~W}$. longitude, in the Beartooth Mountains of Montana, in the central Rocky Mountains of the United States. The glacier is located at about $3000 \mathrm{~m}$ elevation in a northward-facing depression where it receives maximum shading from the sun and maximum snow deposition. It is similar in size and aspect to several other glaciers in the area, none of which have been intensively studied. The area is one of the three major concentrations of glaciers in the U.S. Rocky Mountains (Graf 1977). The glaciers are thought to be remnants of the Little Ice Age, rather than dating back to the more widespread and older Pinedale Glaciation (8-23000 years BP) (Gurney 1953).

This glacier was named because of remains of numerous grasshoppers found on the surface and within the ice of the glacier. In 1952, grasshoppers from the lower part of the terminal face were dated by Irving Friedman of the U.S. Geological Survey, using carbon-14 methods, in an attempt to support the age estimates of the glacier. His results were unreliable, but they did support the idea of the glacier being Holocene in age (Gurney 1953). When the author visited the glacier in 1981, the grasshoppers were scarce or non-existent.

The glacier has not been monitored on a regular basis and very few maps have been compiled of the area, but it has been visited, studied, photographed, occasionally mapped, and described by scientific and non-scientific groups since the first recorded visit in 1898. These photographs (both ground and aerial), together with cartographic and written records, make it possible to trace the fluctuations of this glacier since 1898 and estimate quantitatively, for the first time, the amount of recession that has taken place. AVAILABILITY OF CARTOGRAPHIC, PHOTOGRAPHIC,
OR OTHER REMOTELY-SENSED DATA

Other remotely-sensed data were also looked at as a possible source of information on the changes in Grasshopper Glacier, but none were useful.

Because of the scarcity of map, aerial-photographic, or other remotely-sensed data, the following discussion of glacier fluctuation is therefore based on the available cartographic and aerial-photographic data, ground photography, and verbal descriptions from many visitors to Grasshopper Glacier through the years.

\section{FLUCTUATION OF GRASSHOPPER GLACIER}

The first documented visit to Grasshopper Glacier was made by James P. Kimball and his surveying party, in August, 1898 (Kimball 1899). Kimball was accompanied by a photographer named A.B. Wilse, who took photographs of the glacier (see fig.1). The glacier was described as being very active. The minimum slope of the surface was considered to be $25-30^{\circ}$. The map produced by Kimball at 1:125000 depicts the glacier with a poorly-defined boundary. The best estimate of the glacier area in 1898, based on the map, Wilse's photographs, and verbal description, is $0.82 \times 10^{6} \mathrm{~m}^{2}$.

William C. Alden visited the glacier on July 14, 1922. Alden, a geologist with the U.S. Geological Survey, was requested by the National Park Service to make an examination of Grasshopper Glacier. He estimated the glacier to be $800 \mathrm{~m}$ from front to back and $1.6 \mathrm{~km}$ from side to side (Alden, unpublished). Alden documented his visit with ground photographs.

In August of 1939, S.A. Macauley (Macauley 1940) visited the glacier and described a vertical ice cliff at the toe of the glacier, $15 \mathrm{~m}$ high.

Dr J.R. Parker visited the glacier several times between 1918 and 1949 (Gurney 1953). In Dr Parker's estimation, the glacier appeared in 1918 much as it did in Wilse's photograph of 1898. In visits in 1922 and about 1926, the general appearance remained the same. The ice cliff at that time was $15-23 \mathrm{~m}$ high. During a visit in 1931, he estimated the face was $8 \mathrm{~m}$ lower. In 1949, Dr Parker found the face had receded by melting, and there was a gentle upward slope to the snow-covered ice against the mountain.

In September 1949, the first aerial photography was flown over the area. Using this photography, the surface area of the glacier was planimetrically estimated to be 0.58 $\times 10^{6} \mathrm{~m}^{2}$.

In 1967, Donald Alford and Robert Clark carried out a mass-balance study on Grasshopper Glacier. They described the glacier as being $1 \mathrm{~km}$ wide by $0.5 \mathrm{~km}$ long. Their mass-balance figures show net ablation in the center of the glacier, net accumulation on the sides, and an overall, specific, mass balance of $\pm 0.81 \mathrm{~m}$ of water equivalent (Alford and Clark 1968). In 1968, Donald Alford repeated his study and determined a specific net mass balance of $\pm 0.53 \mathrm{~m}$ (Alford 1970). However, records from the closest weather station show that precipitation was substantially above average in 1967 and 1968.

In August 1981, the glacier was visited by the author. In contrast with 1898 , the glacier was very inactive. Photographs were taken to compare with many of the historic photographs and to document the current glacier conditions. In some cases, it was impossible to duplicate historic photographs taken on the ice surface, because the surface itself had melted to a considerably lower level in the intervening years and it was impossible to obtain the same perspective. A specific photograph of the glacier was 


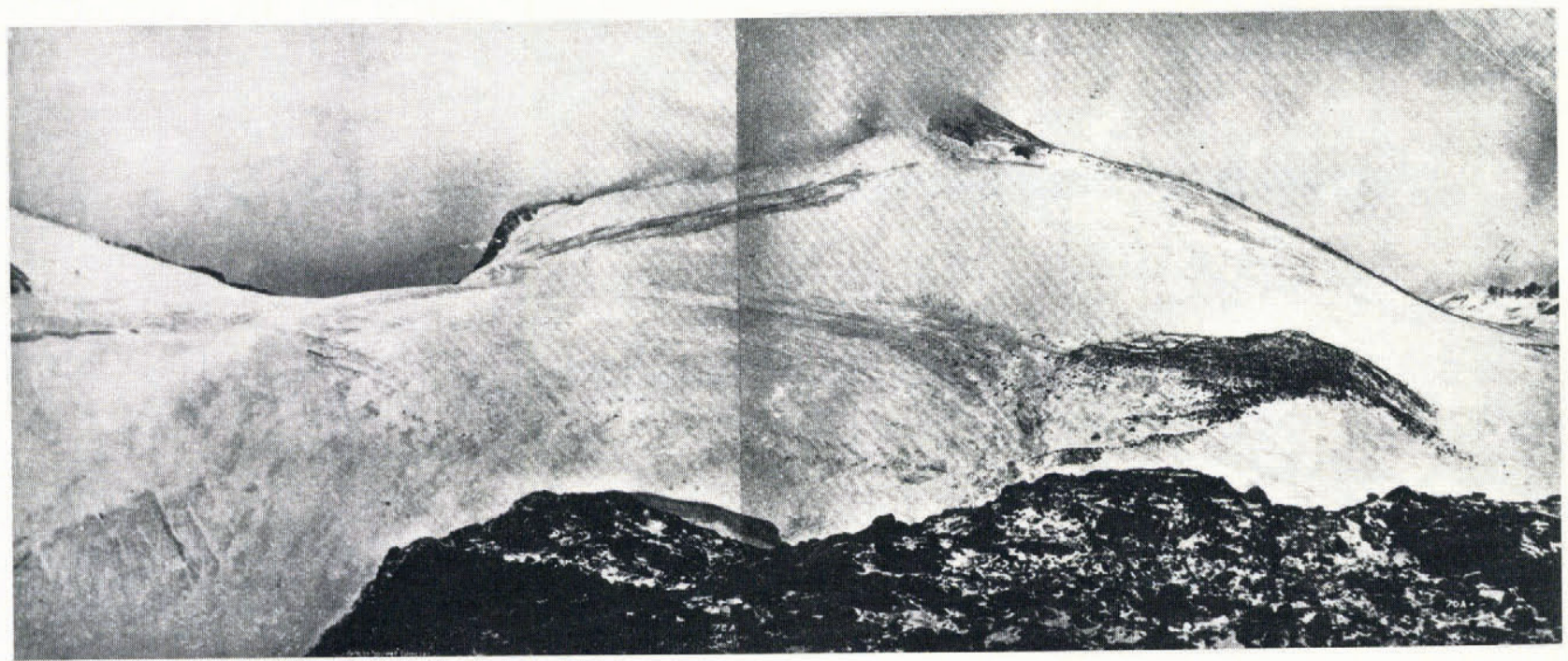

Fig.1. Photograph of Grasshopper Glacier, taken in 1898 by A.B. Wilse.

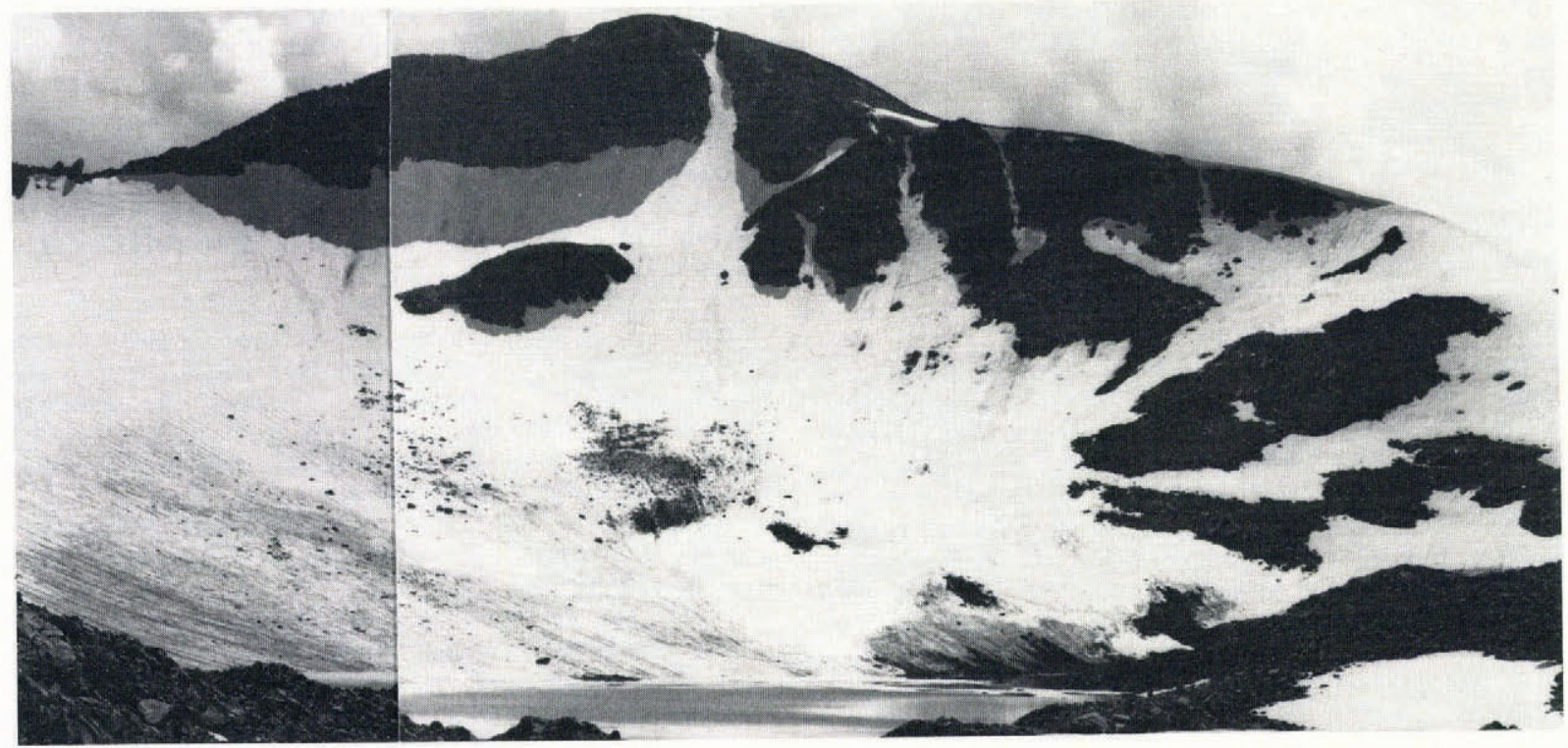

Fig.2. Photograph of Grasshopper Glacier, taken in 1981 by J.G. Ferrigno.

taken (see Figure 2) for comparison with Wilse's 1898 photograph. Aerial photography, taken two weeks later, showed that the glacier had melted into two separate smaller ice patches. The total surface area of the two parts was determined by planimetry to be approximately $0.425 \mathrm{x}$ $10^{6} \mathrm{~m}^{2}$.

An attempt has been made to try to delineate the recession of the glacier, based on the aerial and ground photographs and the description of the glacier by various visitors since 1898. The results indicate that Grasshopper Glacier has lost about $50 \%$ of its area and as much as $90 \%$ of its volume, during the 83 years between 1898-1981 (see Figure 3).

\section{COMPARISON WITH OTHER ROCKY MOUNTAIN} GLACIERS

Because of the substantial retreat of Grasshopper Glacier, it was decided to review data on other Rocky Mountain glaciers, to see if they showed similar behaviour.

Some of the best studied of the U.S. Rocky Mountain glaciers are those of the northern Rockies in Glacier National Park, Montana. The largest of these are the Grinnell and Sperry Glaciers. The Grinnell and Sperry
Glaciers were discovered in 1887 and 1895, respectively. They have been systematically mapped since 1900. Between 1900 and 1966, Grinnell Glacier decreased from $2.15 \times 10^{6}$ $\mathrm{m}^{2}$ to $1.21 \times 10^{6} \mathrm{~m}^{2}$, a $44 \%$ reduction in area. Sperry Glacier decreased from $3.24 \times 10^{6} \mathrm{~m}^{2}$ in 1901 to $1.16 \mathrm{x}$ $10^{6} \mathrm{~m}^{2}$ in 1960 , a $64 \%$ reduction in area (Johnson 1980). These two glaciers are located further north than Grasshopper, but are at a lower average elevation, $2010 \mathrm{~m}$ for Grinnell Glacier and $2380 \mathrm{~m}$ for Sperry Glacier.

Arapaho Glacier was selected as an example of southern Rocky Mountain glaciers. Arapaho is described by Waldrop (1964) as the largest glacier in Colorado and the southernmost active glacier in the Rocky Mountains. Its average elevation is approximately $3870 \mathrm{~m}$. When first studied in 1900, its area was $0.34 \times 10^{6} \mathrm{~m}^{2}$. Between 1900 and 1960 it lost $0.09 \times 10^{6} \mathrm{~m}^{2}$ or about $26 \%$ of its area. Its maximum area was estimated to be $0.46 \times 10^{6} \mathrm{~m}^{2}$, in 1860 (Waldrop 1964).

\section{CONCLUSIONS}

Based on this small sampling, it would appear that, with the exception of a few minor instances of positive mass balance, the U.S. Rocky Mountain glaciers have been steadily decreasing in size during their historical record. If 


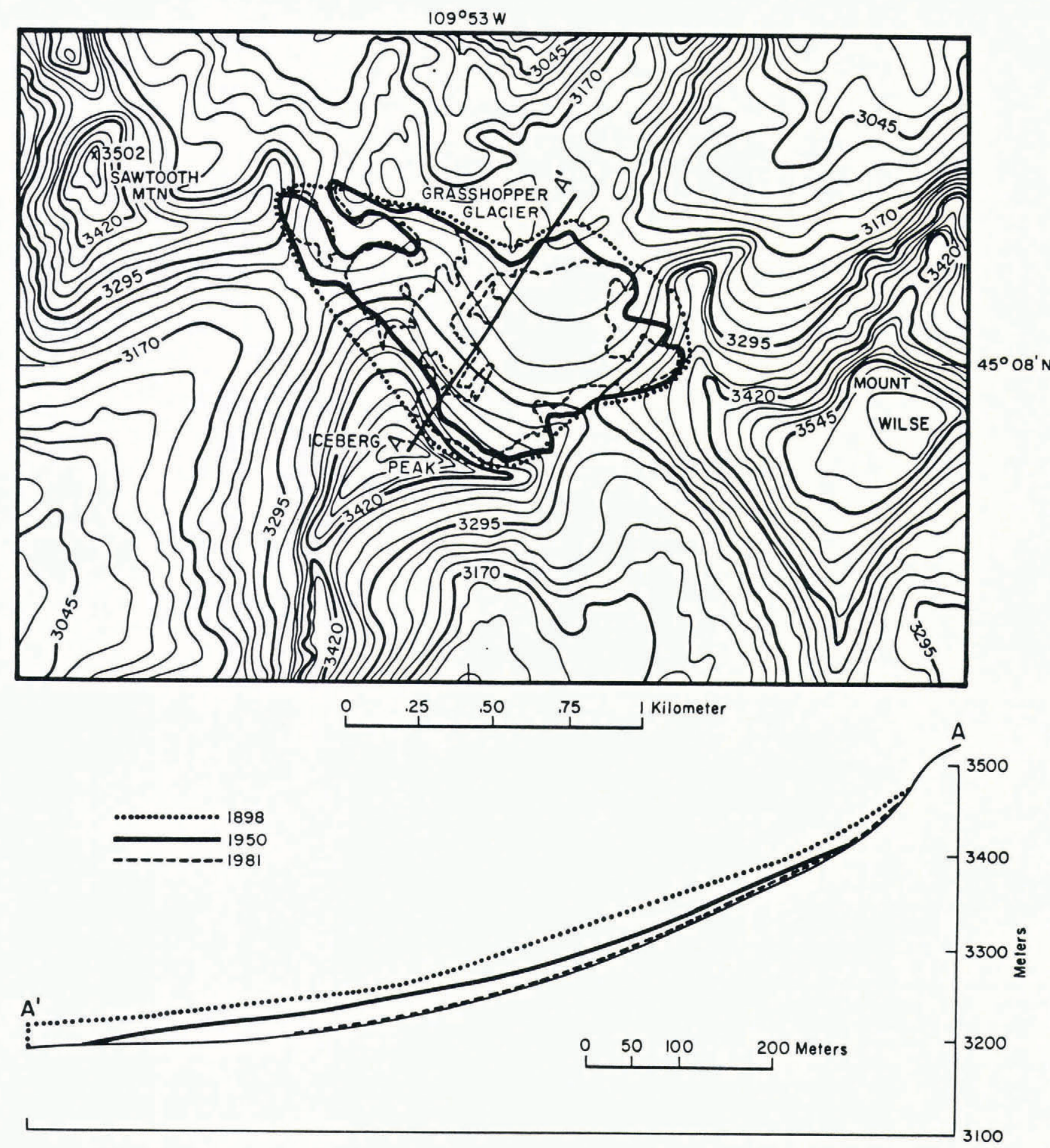

Fig.3. Sketch map and cross-section of the estimated area and thickness of Grasshopper Glacier in 1898, 1950, and 1981. The 1898 profile is an estimate based on a 1:125000-scale Glacier in photographs, and verbal descriptions. The 1950 and 1981 profiles are based on aerial and ground photographs. 
TABLE I. CARTOGRAPHIC AND PHOTOGRAPHIC INFORMATION MOST USEFUL FOR EVALUATION OF FLUCTUATIONS OF GRASSHOPPER GLACIER

Maps

\section{$\underline{\text { Title }}$}

$\underline{\text { Date }}$

Reconnaissance Plane-Table Survey

Cooke City, Mont-Wyo

$\mathrm{b} / \mathrm{w}$

August $1921(?)$

July $13-14,1922$

August 1981 of the Granite Mountain District, Montana

1956

Type

$\mathrm{b} / \mathrm{w}$

$\mathrm{b} / \mathrm{w}$

color

Type

$\mathrm{b} / \mathrm{w}$

1898

September 16, 1951

September 1, 1981

Ground Photographs

\section{Date}

August 1898 b/w

color
Source

James P. Kimball

U.S. Geological

Survey

Source

U.S. Geological Survey

U.S. Geological Survey

U.S. Forest Service

Photographer

A.B. Wilse

J.E. Haynes

W.C. Alden

J.G. Ferrigno $\underline{\text { Scale }}$

$1: 125000$

$1: 62500$

\section{$\underline{\text { Scale }}$}

$1: 37400$

$1: 37000$

$1: 15000$

climate conditions and the rate of retreat remain fairly constant, and if these glaciers are representative, the U.S. Rocky. Mountain glaciers will have disappeared by the middle of the next century.

\section{REFERENCES}

Alden W C Unpublished Grasshopper Glacier. (Administrative report to the National Park Service, 1922)

Alford D 1970 Mass-balance studies: Grasshopper Glacier, Montana. Arctic and Alpine Research 2(1): 75-79

Alford D, Clark R 1968 The 1967 mass balance of Grasshopper Glacier, Montana. Northwest Science 42(3): 115-123

Graf W L 1977 The distribution of glaciers in the Rocky Mountains of the United States. Journal of Glaciology 18(79): $325-328$

Gurney A B 1953 Grasshopper Glacier of Montana and its relation to long-distance flights of grasshoppers. Annual Report of the Board of Regents of the Smithsonian Institution for the year ended June 30, 1952: 305-326 (Publication 4111)

Johnson A 1980 Grinnell and Sperry glaciers, Glacier National Park, Montana - a record of vanishing ice. US Geological Survey. Professional Paper 1180

Kimball J P 1899 The granites of Carbon County, Montana - a division and glacier field of the Snowy Range. American Geographical Society. Bulletin 31(3): 199-216

Macauley S A 1940 Two miles high on Grasshopper Glacier. Travel 75(3): 37-40

Waldrop H A 1964 Arapaho Glacier; a sixty-year record. University of Colorado Studies. Series in Geology 3 